Absolutely not. The State of the System: A Reality Check on Canada's Schools is a wellwritten and cleverly argued populist treatise seemingly designed to diminish a system designed for the public good and refashion it for private benefit. Few readers will be deceived by Bennett's argumentum ad populum — appeal to the people.

Charles Ungerleider

University of British Columbia

\title{
Catherine Gidney \\ Captive Audience: How Corporations Invaded Our Schools
}

Toronto, ON: Between the Lines, 2019. 248 pp.

Because I study education privatization, Catherine Gidney's Captive Audience: How Corporations Invaded our Schools caught my eye when browsing my university's bookstore. I hoped I might learn something new about this phenomenon and confirm I had not overlooked any key studies in my own research. I was not disappointed. Based on an extensive review of primary and secondary sources, Captive Audience offers a unique and detailed history of corporate involvement in Canadian schools. It also illustrates foundational ideas about policy that I aim to teach in my classes. Finally, as a scholar striving to persuade the general public to resist education privatization, the book provides an excellent example of how research can be mobilized to a broad audience as part of efforts to strengthen democracy in Canadian schools.

Captive Audience makes a unique contribution to knowledge about education privatization in Canada. Policy scholars Stephen Ball and Deborah Youdell have identified two types of education privatization: "exogenous privatization," which sees the private sector taking on roles once provided by the public sector; and "endogenous privatization," which involves making the public sector more like the private one. ${ }^{1}$ Gidney focuses primarily on exogenous forms of privatization by examining how corporations have sought to benefit through their involvement with schools. With its Canadian focus, this book makes an original contribution to the international literature on educational privatization while offering new knowledge to the growing body of research on the phenomenon in Canada. By demonstrating that corporations have actively engaged with Canadian public education systems for close to 100 years, the book can help scholars understand how and why the trend toward education privatization across Canada continues. However, it also shows that education privatization has always been contested - sometimes successfully. Further, Captive Audience challenges the common assertion that education privatization is an outcome of neoliberalism, although Gidney acknowledges that corporate

1 Stephen J. Ball and Deborah Youdell, Hidden Privatisation in Public Education (Brussels: Education International, 2007), https://pages.ei-ie.org/quadrennialreport/2007/upload/content_trsl_ images/630/Hidden_privatisation-EN.pdf 
involvement took on new forms as this ideology became dominant throughout the 1980s. The historical perspective offered in the book helps to situate emerging research on the ways education technology ("ed tech") companies benefitted from the turn to online schooling during the COVID-19 pandemic. The text shows that while the crisis may have created ideal conditions for their further involvement, it is yet another moment in long trajectory of businesses attempting to profit from public education.

Gidney shows that while corporations have been involved in public schools since at least the 1920s, the nature, scope, and entrenchment of their involvement has changed. Their engagement, she argues, has endangered children's health and promoted a consumerist culture at the expense of teaching critical reflection and developing students' creativity, personal development, and well-being. Following a brief introduction, the first chapter discusses various ways businesses acted creatively and deliberately to promote their products and values in schools in the 1930s-1970s. Their efforts included supplying teaching aids, hosting essay and poster contests, sponsoring student trips, inviting students to serve as advisors to department stores, and providing professional development for educators. Later chapters in the book, including one that discusses the rise of school-business partnerships and another that examines the push to supply schools with computers, demonstrate that through the 1980s and 1990s businesses - with the support of some government leaders, educators, and parents - advocated for more closely aligning curriculum with the needs of the economy. Gidney outlines the effects of different kinds of corporate involvement on students, society, and democracy in the conclusion rather than throughout the text. Consequently, at the end of each chapter I found myself wondering what Gidney believed were the effects of the type of corporate involvement just discussed and how they differed from other forms of engagement (e.g., how are the effects of advertising different from consequences of promoting entrepreneurialism or corporate donations?). Similarly, in the introduction and conclusion Gidney asserts that the presence of and reliance on corporations in schools raise important questions about the purposes of public education, who should pay for it, and how it should be governed. I agree, but I felt somewhat disappointed that Gidney does not share her responses to the questions she poses.

Individually and collectively the chapters illustrate key ideas and critical understandings about policy. First, Gidney shows that education policy is political. In discussing debates over the Youth News Network (YNN) and junk food in schools, for instance, she highlights the arguments and strategies advocates and opponents used in efforts to convince others to adopt their policy preferences. Second, Gidney shows how what happens outside the education sector impacts schools. For example, she discusses how shifting financial and ideological contexts between the mid1950 s to 1990 s supported the growth of school business-partnerships, and how the healthy food movement and growing concerns about childhood obesity in the 1970s in Canada affected decisions about what could be sold in school cafeterias. Third, Gidney demonstrates that policies are invariably enacted differently at local sites in part due to the preferences, influence, and idiosyncrasies of the people in each place 
as well as differences in their social and geographical contexts. Finally, the cases illustrate that policy is made at multiple levels (i.e., by teachers, principals, district leaders, and government officials) and that their engagement, influence, and autonomy vary depending on the issue. In the case of corporate sponsorships, for instance, Gidney recounts how some governments have actively tried to limit corporate involvement in education, while others have left the issue to school boards to manage. In turn, some boards have left decisions about sponsorships to individual principals. I envision drawing on Captive Audience to teach students about education policy.

Part of what makes Captive Audience compelling is how Gidney presents her arguments. In plain language, she provides numerous, detailed descriptions of businesses' activities and ensuing debates over their involvement. Photos, advertisements, and quotations from advocates and critics provide compelling evidence to support her points and bring the text alive. The result is a very readerly text that will appeal to a broad audience and inevitably prompt them to weigh the costs and benefits of corporate involvement in public education.

Sue Winton

York University

Denis Simard, Jean-François Cardin et Olivier Lemieux (dir.)

La pensée éducative et les intellectuels au Québec. La génération 1900-1915

Québec : Presses de I’Université Laval, 2020. 250 pp.

Cet ouvrage est le deuxième que ces éditeurs et les auteurs qu'ils ont réunis consacrent à la pensée éducative au Québec. Le premier, que j'ai recensé dans une précédente publication (volume 32, printemps 2020), portait sur la génération 1915-1930 (https://historicalstudiesineducation.ca/index.php/edu_hse-rhe/issue/view/447). Cette fois encore, je veux d'abord souligner l'importance qu'il y a, à mon sens, à s'intéresser et à faire connaître la trop négligée histoire de l'éducation - en général et celle du Québec en particulier — et ce, notamment en raison du recul qu'elle permet de prendre sur l'actualité, des éclairages que ce recul permet de donner sur son objet, sans rien dire de l'intérêt intrinsèque qu'il y à savoir d'où l'on vient, qui peut en outre aider à décider où l'on devrait aller.

L'ouvrage s'ouvre sur une brève introduction des trois éditeurs qui rappellent ce qu'il convient d'entendre dans leur livre par " pensée éducative " et par " intellectuel », et les raisons pour lesquelles ils ont retenu cette approche générationnelle. Ces précisions sont cruciales. Attardons-nous-y.

\section{Pensée éducative, intellectuel, approche générationnelle}

La pensée éducative dont il sera question est « une réflexion plus ou moins explicite, voire implicite sur l'éducation " qui avance des principes, valeurs, finalités, visées, 